\title{
Field Evaluating of Wetting Pattern from Surface Drip Irrigation System for Sand and Sandy Loam Soils
}

\author{
Ahmad Dnan Abbass ${ }^{1}$, and Hayder A.K. AL-Thamiry ${ }^{2, *}$ \\ ${ }^{1}$ College of Engineering, Baghdad University, Baghdad, Iraq, engnahmad_2014@yahoo.com \\ ${ }^{2}$ College of Engineering, Baghdad University, Baghdad,Iraq, hy_hyder@coeng.uobaghdad.edu.iq \\ *Corresponding author: Ahmad Dnan Abbass and email : engnahmad_2014@yahoo.com \\ Published online: 30 June 2019
}

Abstract- Water distribution through soils from trickle source is very important issue since it affects irrigation efficiency, wetted surface area and wetted soil profile. Many attempts to determine wetting pattern under drip irrigation using mathematical and numerical models were carried out. The verification of the validity of which model will be suitable for Iraqi soils need a detailed study. In this paper, the field work measurements of wetted pattern in two Iraqi soils (sand and sandy loam) were conducted to investigate the validity of the application of wetting pattern formulas predicted by Dawood (2016), Amin and Ekhmaj, (2006) and Schwartzman and Zur (1986). The work was divided into two parts: the first one was the laboratory work of soil texture, field capacity, permanent wilting point, and soil porosity. The second one includes field operations through landing, installation of trickle irrigation system, installation of equipment's and sensors, adjustment of emitter discharge by the valve on the supply pipe. In each run, initial water content was measured and the system was operated for three continuous hours with three different discharges, discharges were selected as 1,3 and $61 / \mathrm{hr}$. the wetted diameter and depth were recorded hourly during each run test.The field measurements of wetted area were compared with that predicted by the previous studies. The obtained result indicate that the value of the wetted diameter and depth increase with increasing of water contents, the wetted diameter are inversely proportional was saturated hydraulic conductivity, and the wetted depth was directly proportional to the saturated hydraulic conductivity. Amin and Ekhmaj 2006 formula was suitable for wetted depth in sandy loam soil with average error $13.40 \%$ and Schwartzman and Zur, 1986 formulas gave a good prediction for wetted diameters with average error $12.79 \%$ for same soil. Finally Dawood (2016) formulas were more suitable than others for sand soil with average error for wetted diameter and depth $11.49 \%, 16.79 \%$ respectively.

Keywords - Wetting pattern, drip irrigation, wetted diameter, field evaluating.

\section{Introduction}

Drip irrigation is one of the ways of controlling the irrigation water currently spread throughout the world. This method is based on the principle of running water under low pressure. This water is discharged into the fields by means of systems through spaced holes called emitters (1). Drip irrigation is the least water consumption and less expensive as the water moves horizontally and vertically at a slow speed according to the type of soil texture component of the moisturizing area. This area is the most important as it is the area of root extension. The objective of this system is to provide water to limited soil position where the root uptake may predict. If the wetted front is known, the location of emitter will be easy specified and plant will take water efficiently. Several Researchers used mathematical and numerical models to determine water distribution and wetting pattern under drip irrigation with many assumptions that may cause errors in prediction.

The verification of the validity of which model will be suitable for Iraq soil need a detailed study. So, the present study problem is the field work measurements of wetted pattern in two different Iraqi soils to investigate the validity of the application of wetting pattern equations that found by Dawood (2016), Schwartzman and Zur, 1986 and Amin and Ekhmaj, 2006. Information about the wetted bulb in a given soil is helpful to find spacing between the emitters and the irrigation time of application as a function of the soil bulb where the crop roots are located (3). 


\section{The objectives of study}

The objectives were listed according to the priority as:

1- Field measurements of wetting pattern in two irrigation projects soil by surface emitter with different irrigation time, initial water contents and emitter discharges to investigate water distribution through soil profile.

2- Investigate applicability of the wetting pattern equations that found by Dawood (2016) according to United States Department of Agriculture (USDA).

3- Investigate the validity of other famous equations or formulas which field.

\section{Locations of field work sites}

The selected sites were Karrbala (P1) and Baghdad (P2) as showed in Table (1).

\subsection{Karrbala site (P1)}

The site was chosen within the green belt project in Karbala Governorate. The project area was 1080Donums with a length of $27 \mathrm{~km}$ and a width of $100 \mathrm{~m}$. The project was extending southeast and northwest of Karbala. Generally, the top soil within it was featured as high permeable soil. It was planted with perennial and fruitful trees such as palm trees, olives and cappuccinos. It was started in 2006, contains 50 wells. The irrigation method used surface drip irrigation. The project was one of the important projects in this governorate where it was a barrier to wind in addition to aesthetics and production, managed by Karbala Agriculture Directorate (8).

\subsection{Baghdad Abi Gharib site (P2)}

The project includes land between the Governorate of Baghdad in the east and the Euphrates River in the west, the project of Saqlawiyah in the north and Yusufiya in the south. The total area was 3400000 Donums. The main source of irrigation is the Euphrates River, feeding unlined channel with a discharge of $38 \mathrm{~m} 3 / \mathrm{s}$. The experiment was conducted at the pilot project site Water Users Associations. It was located at southwest of Baghdad .It was irrigated from a branch of the South Abi Gharib canal named AS-00.lind $21 \mathrm{~km}$, discharge 7. 57 m3/s. (9)

Table 1: Locations of the selected sites for the field work.

\begin{tabular}{|c|c|c|c|c|c|}
\hline No. & $\begin{array}{c}\text { Name of } \\
\text { project }\end{array}$ & Symbol & $\begin{array}{c}\text { Field } \\
\text { Hydraulic } \\
\text { conductivity } \\
\mathrm{cm} / \mathrm{hr}\end{array}$ & \multicolumn{2}{|c|}{ Location } \\
\cline { 4 - 6 } & & $\begin{array}{c}\text { Northing. } \\
m\end{array}$ & $\begin{array}{c}\text { Easting. } \\
m\end{array}$ \\
\hline 1 & Karbala & $\mathrm{P}_{1}$ & 28.60 & 3605218 & 404064 \\
\hline 2 & Baghdad & $\mathrm{P}_{2}$ & 7.15 & 3685462 & 412670 \\
\hline
\end{tabular}

\section{Laboratory work}

Soil samples were taken from the two field sites and tested in the laboratory of the University of Baghdad / College of Agriculture.

The laboratory tests consists of soil texture, field capacity, permanent wilting point and porosity. As showed in Table (2).

Table 2 : Laboratory tests of soil texture, field capacity and permanent wilting point and porosity of the selected sites

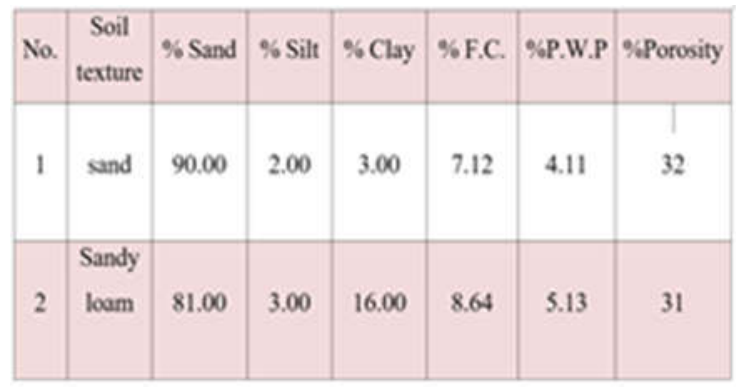

\section{Previous studies}

\subsection{Schwartzman and Zur (1986).}

They found empirical equations (12).

$\mathrm{W}=27.28(\mathrm{~V}) 0.22(\mathrm{Ks} / \mathrm{Q}) 0.17 \ldots$ (1)

$\mathrm{Z}=9.24(\mathrm{~V}) 0.63(\mathrm{Ks} / \mathrm{Q}) 0.45$

Where:

$\mathrm{W}=$ wetted diameter, $\mathrm{cm}$.

$\mathrm{Z}=$ wetted depth, $\mathrm{cm}$.

$\mathrm{V}=$ applied volume water, 1 .

$\mathrm{Q}=$ discharge of the emitter, $\mathrm{l} / \mathrm{hr}$.

$\mathrm{Ks}=$ soil saturated hydraulic conductivity, $1 / \mathrm{hr}$.

$\Delta \theta$ : average change of volumetric water content

\subsection{Amin and Ekhmaj (2006).}

Their models were developed as (1).

$\mathrm{W}=12.45 * \Delta \theta-0.5626 *(\mathrm{~V})-0.6286 *(\mathrm{Q})-0.0028 \quad *(\mathrm{Ks})-$ 0.038

$\mathrm{Z}=6.19 * \Delta \theta-0.5626^{*}(\mathrm{~V})-0.6286^{*}(\mathrm{Q}) 0.0028$

* (Ks) -0.038

\subsection{Dawood (2016)}

predicted empirical formulas for wetted diameter and depth that were listed in Tables (3) and (4) for three different soils using USDA soil classification system. 
These formulas will be used to find the wetted diameter and depth by interpolation with respect to hydraulic conductivity (5).

Table 3: Formulas of prediction wetted diameters after Dawood (2016). (5)

\begin{tabular}{|c|c|c|}
\hline No. & $\mathrm{Ks}$ & Wetted diameter \\
$\mathrm{km} / \mathrm{cm}$
\end{tabular}

Table 4 : Formulas of predicted wetted depth after Dawood (2016). (5)

\begin{tabular}{|c|c|c|}
\hline & Ks & Wetted depth \\
\hline & $c m / h$ & $c m$ \\
\hline 1 & 29.7 & $36.59 Q^{0.396} \mathrm{t}^{0.547} \theta^{0.273}$ \\
\hline 2 & 14.60 & $36.82 Q^{0.350} \mathrm{t}^{0.531} \theta^{0.365}$ \\
\hline 3 & 4.42 & $19.39 Q^{0.340} \mathrm{t}^{0.533} \theta^{0.250}$ \\
\hline
\end{tabular}

\section{Results and Discussions}

The obtained results of the wetted diameter and depth of field measurements from two sites; indicated that the same behavior in water movement in the two soil types but with different values according to soil properties and saturated hydraulic conductivity.

The following main significant remakes were listed as:

1-The value of wetted diameter and depth were increased with increasing time and water content in two sites Figures $(1,2,3,4,5,6,7$ and 8$)$ which presented the variation of wetted diameter and wetted depth with time at different initial water content for two sites. The wetted diameter in soils of low saturated hydraulic conductivity was affected significantly by the initial water content.

2-The wetted diameter was inversely proportional with the saturated hydraulic conductivity. Where the maximum wetted diameter is measured in $\mathrm{P} 2$ with saturated hydraulic conductivity of $7.15 \mathrm{~cm} / \mathrm{hr}$ is $50 \mathrm{~cm}$ at the end of irrigation while the lowest was $41 \mathrm{~cm}$ in the $\mathrm{P} 1$ with hydraulic conductivity of $28.6 \mathrm{~cm} / \mathrm{hr}$.
3-The wetted depth was directly proportional to the saturated hydraulic conductivity. It was observe during the measurements that the lowest depth value of $56 \mathrm{~cm}$ was P2 with saturated hydraulic conductivity of $7.15 \mathrm{~cm} / \mathrm{hr}$, and the largest value of $90 \mathrm{~cm}$ was $\mathrm{P} 1$ with saturated hydraulic conductivity of $28.6 \mathrm{~cm} / \mathrm{hr}$.

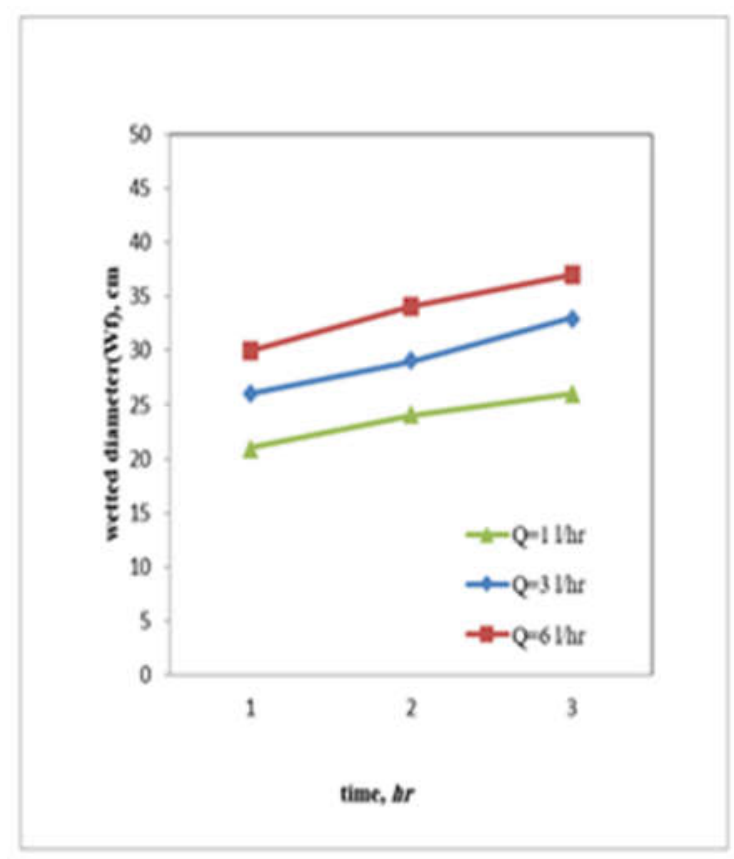

Figure 1 : Variation of wetted diameter with time at initial water content equal to 0.104 for site (P1).

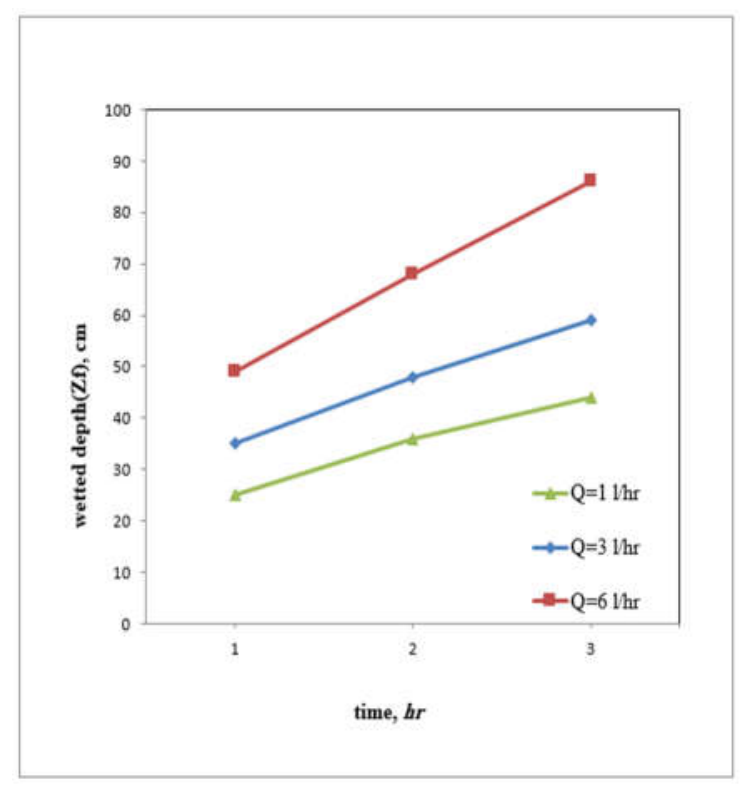

Figure 2: Variation of wetted depth with time at initial water content equal to 0.104 for site $\left(\mathrm{P}_{1}\right)$. 


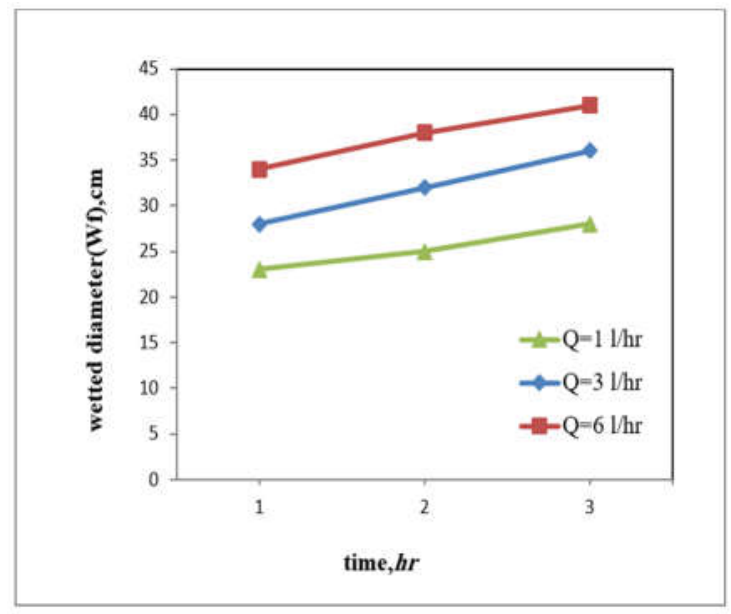

Figure 3: Variation of wetted diameter with time at initial water content equal to 0.2 for site $\left(\mathrm{P}_{1}\right)$.

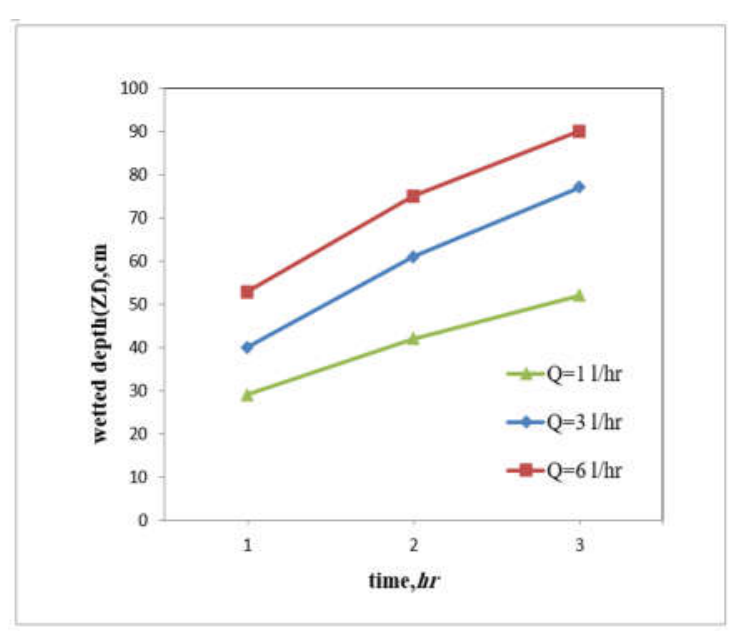

Figure 4: Variation of wetted depth with time at initial water content equal to 0.2 for site (P1).

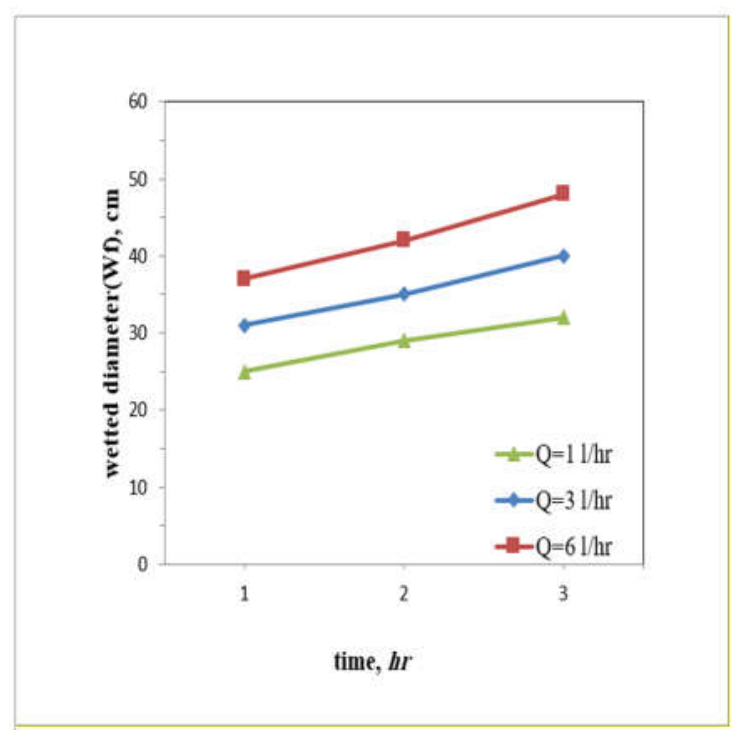

Figure 5 : Variation of wetted diameter with time at initial water content equal to 0.06 for site (P2).

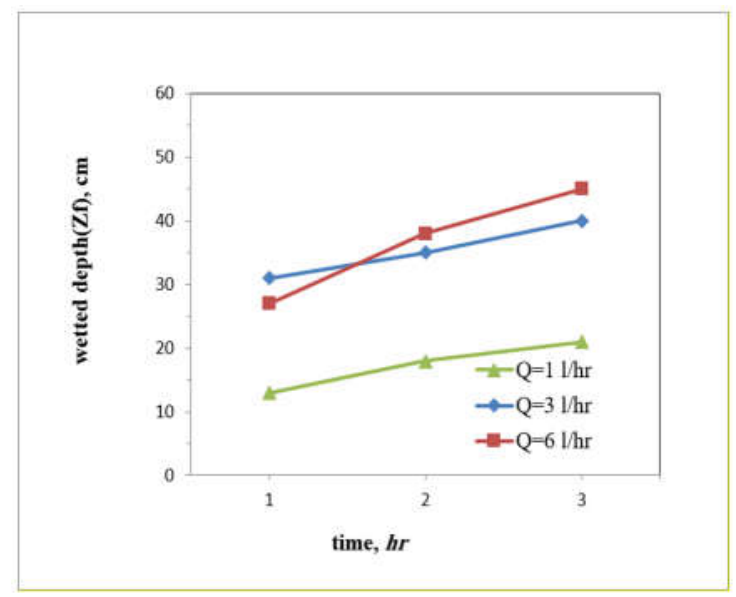

Figure 6 : Variation of wetted depth with time at initial water content equal to 0.06 for site (P2).

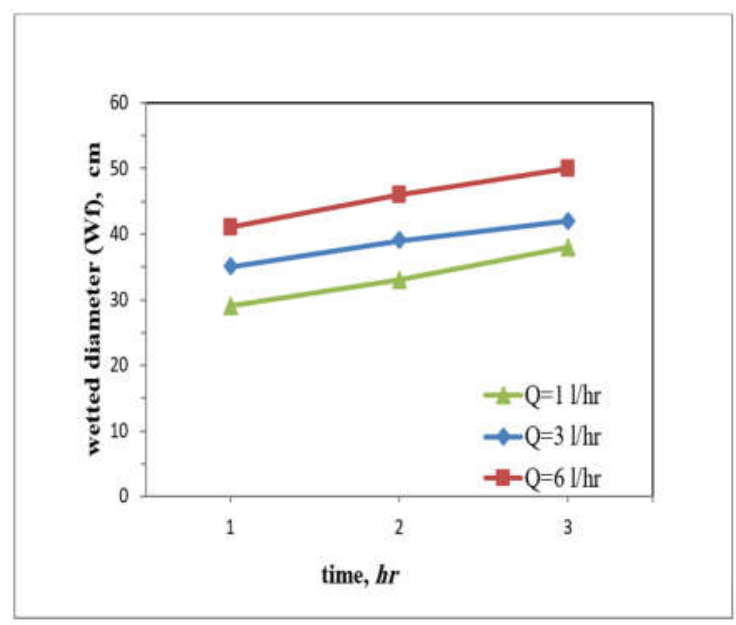

Figure 7: Variation of wetted diameter with time at initial water content equal to 0.2 for site (P2).

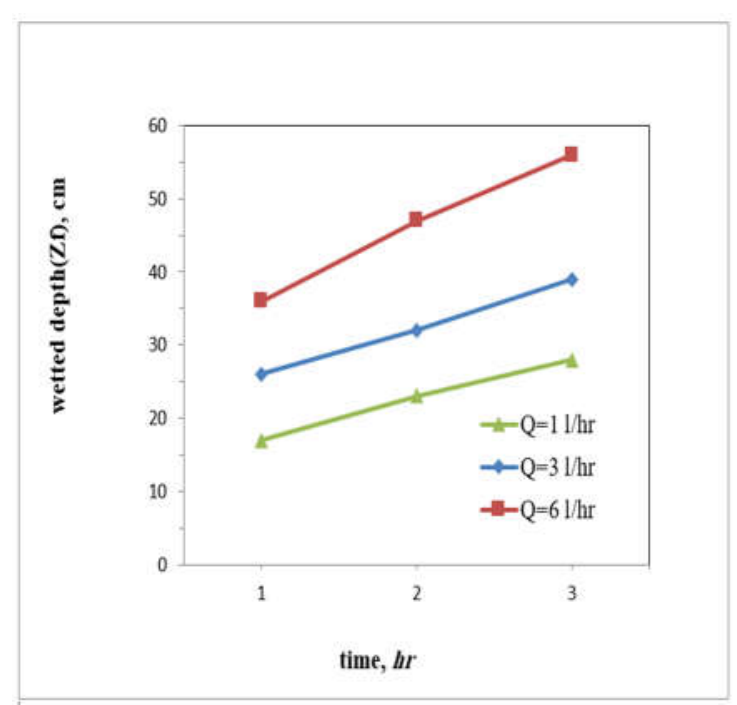

Figure 8: Variation of wetted depth with time at initial water content equal to 0.2 for site $\left(\mathrm{P}_{2}\right)$. 
4- It was noticed from above figures that the field values are close to predicted one in one or more water contents and far with other water content through increased time or moisture content.

Sometimes all values of field and predicted values were close. This behavior depends on the type of soil tissue and physical soil properties as showed in Figures $(9,10,11,12$, $13,14,15$ and 16).

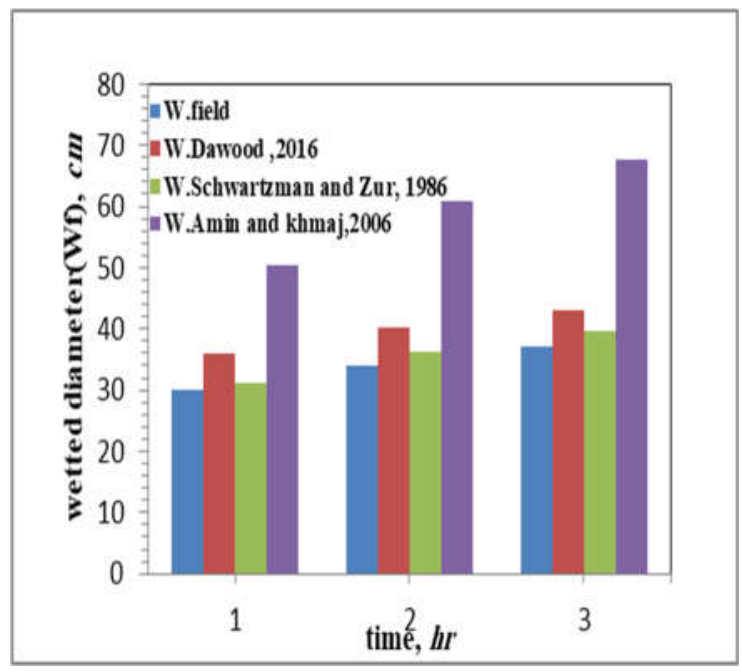

Figure 9: Comparison the variation of wetted diameter of the present work with Schwartzman and Zur, 1986, Amin and Ekhmaj, 2006 and Dawood, 2016 with time at initial water content equal to 0.104 for discharge $61 / \mathrm{hr}$ in site $(\mathrm{p} 1)$.

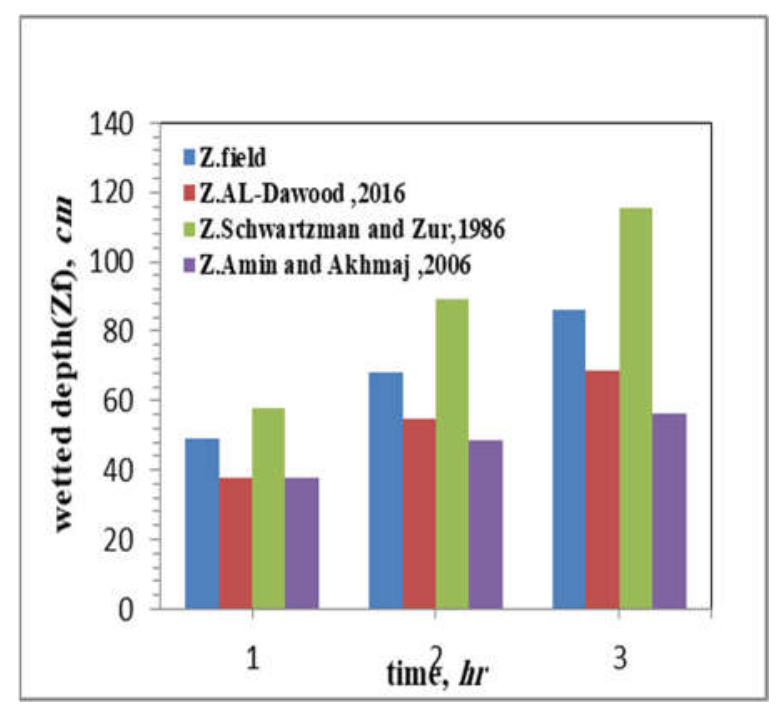

Figure 10 : Comparison the variation of wetted depth of the present work with Schwartzman and Zur, 1986, Amin and Ekhmaj, 2006 and Dawood, 2016 with time at initial water content equal to 0.104 for discharge $6 l / h r$ in site $\left(\mathrm{p}_{1}\right)$.

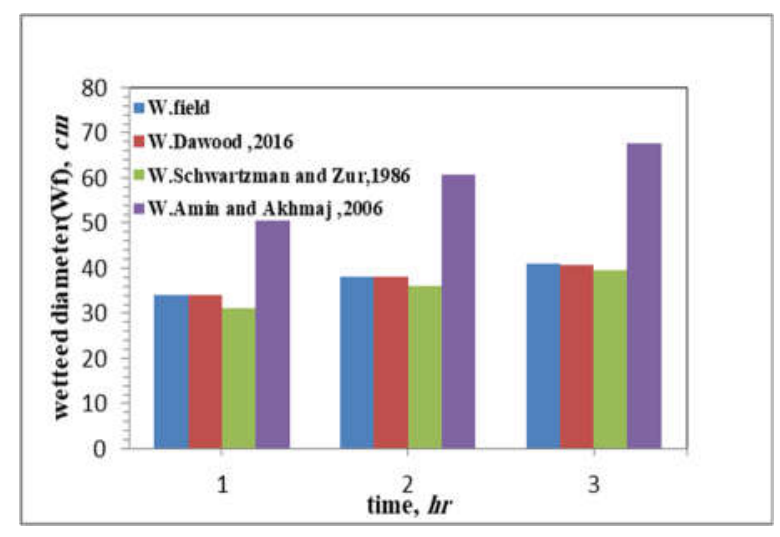

Figure 11 : Comparison the variation of wetted diameter of the present work with Schwartzman and Zur, 1986, Amin and Ekhmaj, 2006 and Dawood, 2016 with time at initial water content equal to 0.2 for discharge $6 l / h r$ in site $\left(\mathrm{p}_{1}\right)$.

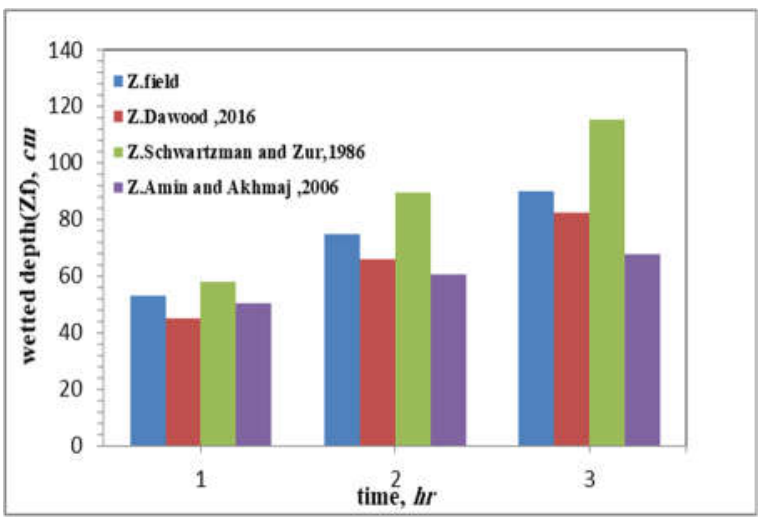

Figure 12 : Comparison the variation of wetted depth of the present work with Schwartzman and Zur, 1986, Amin and Ekhmaj, 2006 and Dawood, 2016 with time at initial water content equal to 0.2 for discharge $6 l / h r$ in site $\left(p_{1}\right)$.

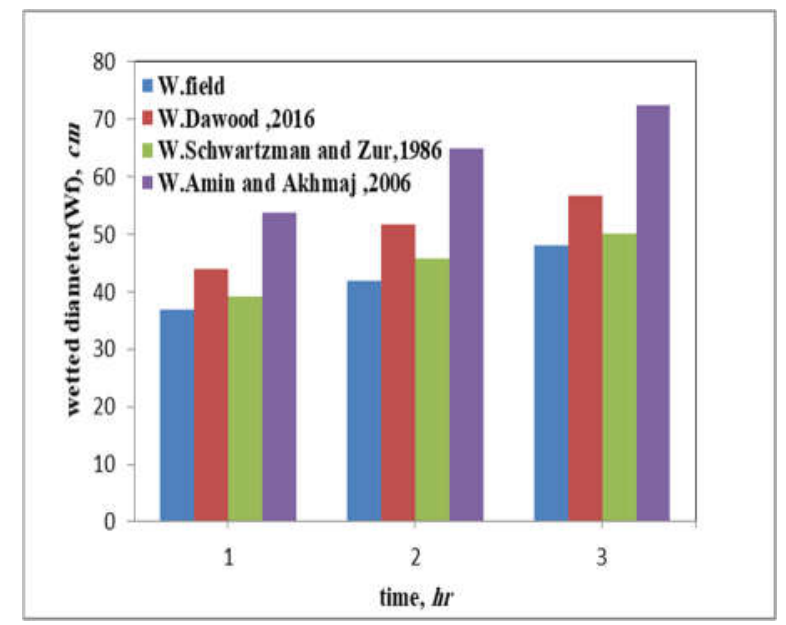

Figure 13 : Comparison the variation of wetted diameter of the present work with Schwartzman and Zur, 1986, Amin and Ekhmaj, 2006 and Dawood, 2016 with time at initial water content equal to 0.06 for discharge $6 \mathrm{l} / \mathrm{hr}$ in site $\left(\mathrm{p}_{2}\right)$ 


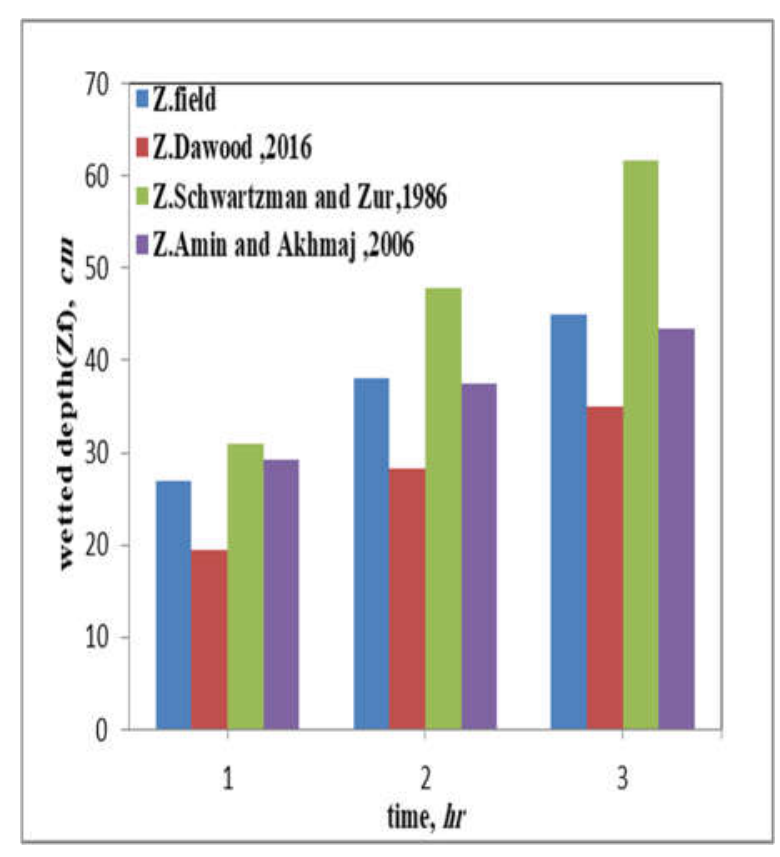

Figure 14: Comparison the variation of wetted depth of the present work with Schwartzman and Zur, 1986, Amin and Ekhmaj, 2006 and Dawood, 2016 with time at initial water content equal to 0.06 for discharge $6 l / h r$ in site $\left(\mathrm{p}_{2}\right)$.

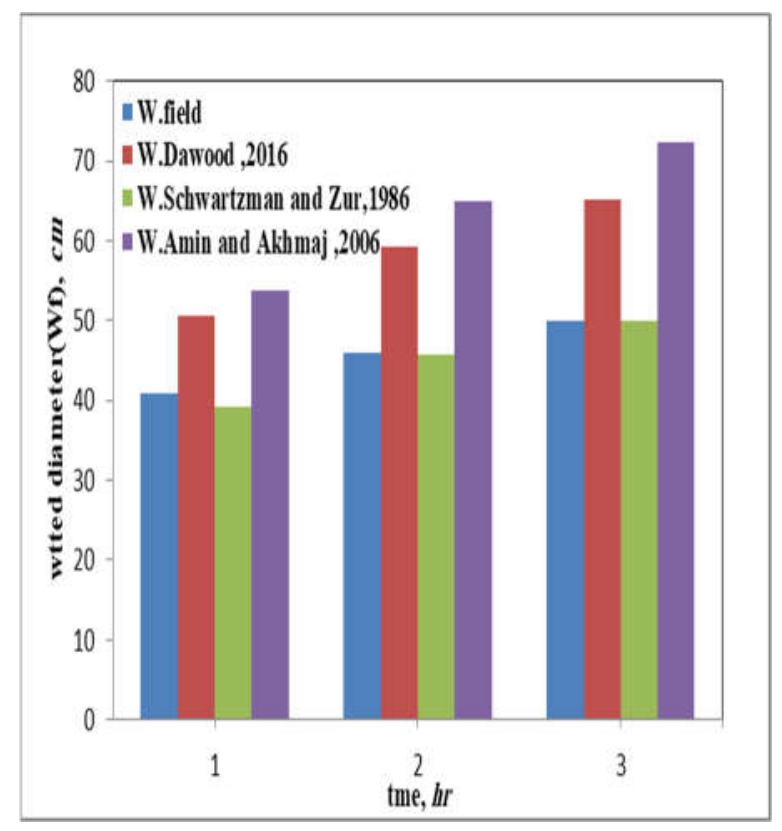

Figure 15 : Comparison the variation of wetted diameter of the present work with Schwartzman and Zur, 1986, Amin and Ekhmaj, 2006 and Dawood, 2016 with time at initial water content equal to 0.2 for discharge $6 \mathrm{l} / \mathrm{hr}$ in site $\left(\mathrm{p}_{2}\right)$.

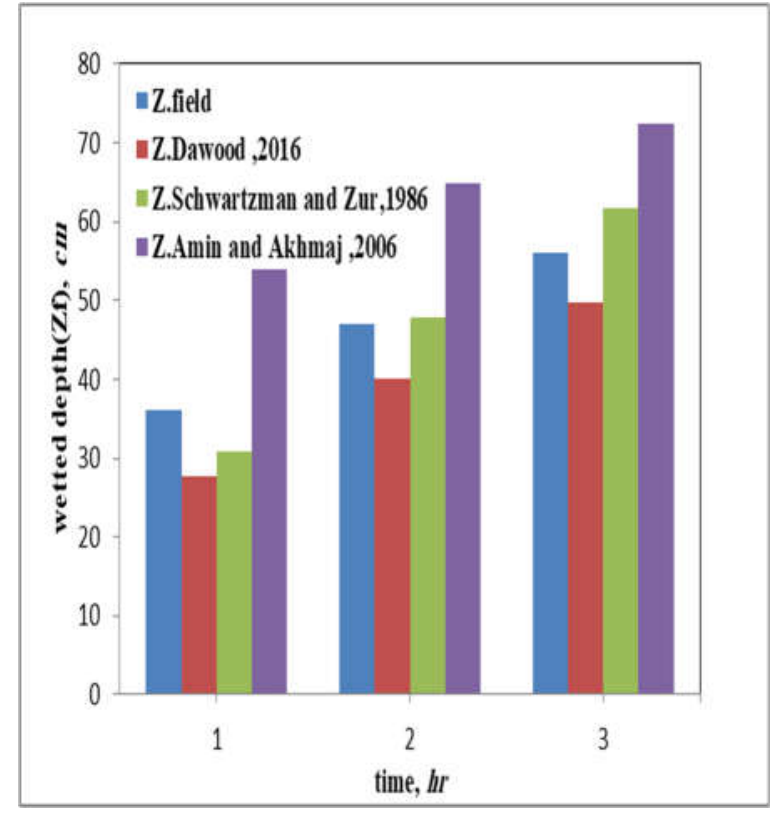

Figure 16 : Comparison the variation of wetted depth of the present work with Schwartzman and Zur, 1986, Amin and Ekhmaj, 2006 and Dawood, 2016 with time at initial water content equal to 0.2 for discharge $6 l / h r$ in site $\left(\mathrm{p}_{2}\right)$.

5-The more compatible formulas with the field measurements need a statistical index. The average error among the field measurements in the present work with values obtained from other studies and according to their zone in the USDA system was adopted. Table (5) presents the average error for two sites according to (USDA) system. It was clear from the table that Amin and Ekhmaj, 2006 formulas were suitable for wetted depth in (sandy loam soil of Ks $7.15 \mathrm{~cm} / \mathrm{hr}$ ) only with average error $13.40 \%$. The main reasons of that differences because they assumed that the average water contents as the porosity divided by two and the soil is homogenous and isotropic.

Schwartzman and Zur, 1986 formulas give good predicted wetted diameters for (sandy loam soil of Ks 7.15 $\mathrm{cm} / \mathrm{hr}$ ), with average error $12.79 \%$. The main reason of limited representation of actual wetted front in the present work because they assumed that the soil was isotropic and they neglect the effect of moisture content in there formulas.

Dawood, 2016 formulas are suitable and can be applied to predict the wetting pattern for sand soil of $\mathrm{Ks} 28.6 \mathrm{~cm} / \mathrm{hr}$, the average errors for wetting diameter and depth were the least and equal $11.49 \%$ and $16.75 \%$ respectively. The situation was clear that the values were emerging by approaching the field values as showed in Figure $(17,18$, 19 and 20) 
Table 5: Average error among the present study field measurements with Dawood, 2016, Schwartzman and Zur, 1986 and Amin and Ekhmaj, 2006 for the two sites according to (USDA) system
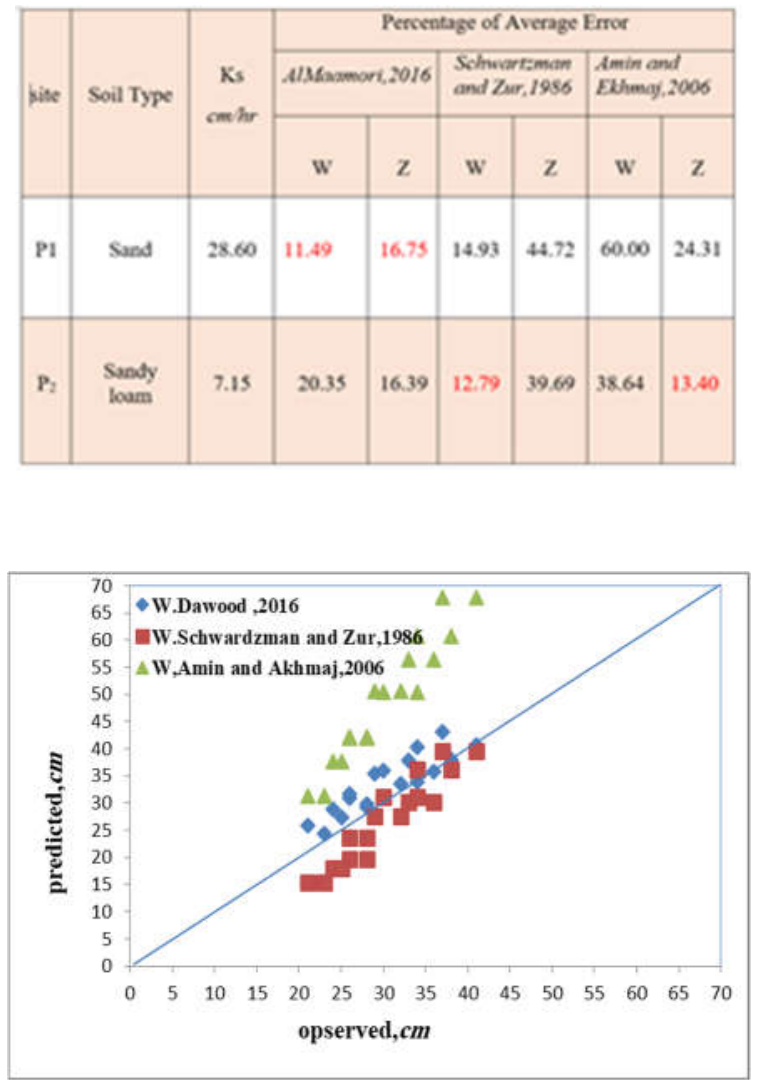

Figure 17: Comparison of all measured wetted diameter with that predicted by other studies in site (P1).

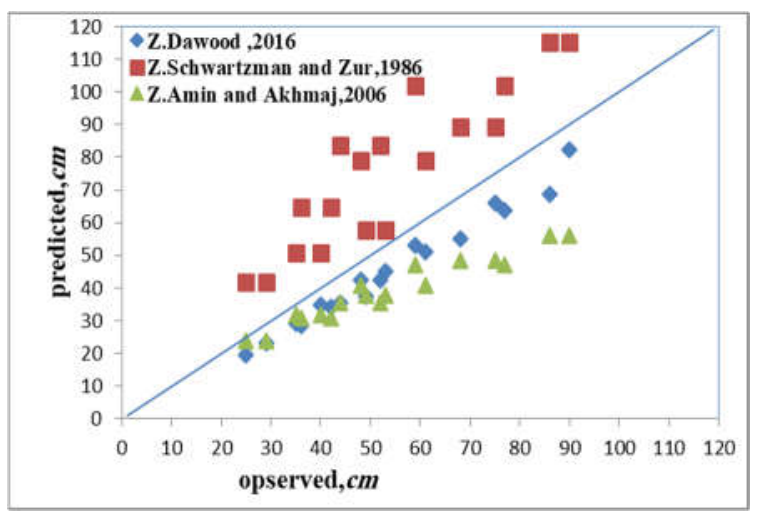

Figure 18 : Comparison of all measured wetted depth with that predicted by other studies in site (P1).

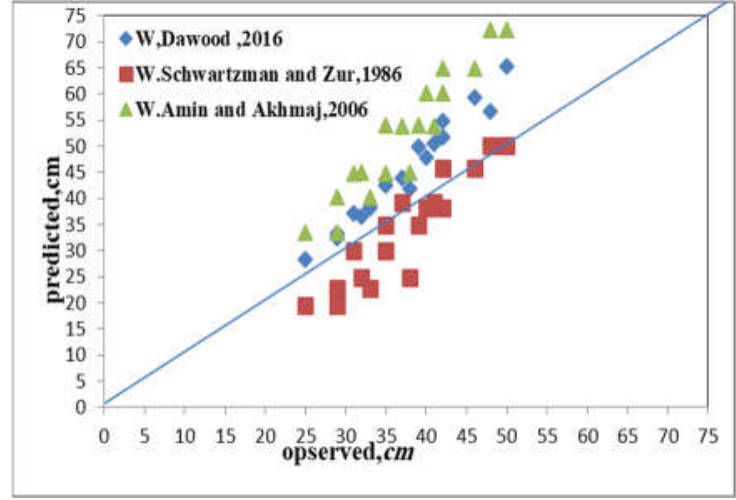

Figure 19: Comparison of all measured wetted diameter with that predicted by other studies in site $\left(\mathrm{P}_{2}\right)$.

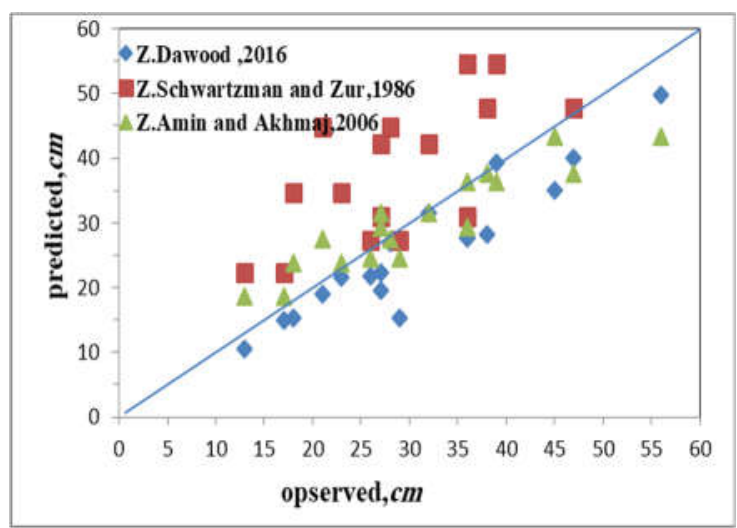

Figure 20 : Comparison of all measured wetted diameter with that predicted by other studies in site $\left(\mathrm{P}_{2}\right)$.

\section{Conclusions}

Depending on the obtained result of the present study as presented in Table (5), the following conclusions were withdrawn.

1- The value of wetted diameter and depth was increase with increasing of water contents for both sites. The wetted diameter was inversely proportional with saturated hydraulic conductivity. Moreover the wetted depth was directly proportional to the saturated hydraulic conductivity.

2- $\quad$ Amin and Ekhmaj (2006) formulas were suitable for wetted depth in sandy loam soil of $\mathrm{Ks} 7.15 \mathrm{~cm} / \mathrm{hr}$ only. 3- Schwartzman and Zur (1986) formulas may be used partially to compute the wetted diameter in sites sandy loam soil of Ks $7.15 \mathrm{~cm} / \mathrm{hr}$.

4- Dawood (2016) formula was recommended to predict the wetted pattern in sand soil of $\mathrm{Ks} 28.6 \mathrm{~cm} / \mathrm{h}$.

\section{Reference}

1-Amin, M. S. M., and Ekhmaj, A. I. M. (2006). "DIPACdrip irrigation water distribution pattern calculator," In: 7th International Miro Irrigation Congress, PWTC, Kuala Lumpur, Malaysis.

2-Al-Temmemi M. and Majeed F. (2015)"Flow in Porous Media " University of Baghdad college of Agriculture and Middle Technical University. 2352:2014. 
3-Boštjan, N., Cedric, K., Frederic, C., and Marina, P. (2014)."Numerical investigation of the influence of texture, surface drip emitter discharge rate and initial soil moisture condition on wetting pattern size," Irrig. Sci., vol. 32, no. 6, pp. 421-436.

4-Carsel, R.F., and Parrish, R. S. (1988). "Developing joint probability distributions of soil water retention characteristics, Water Resource. Vol. 24, pp. 755-769

5-Dawood I. A. (2016) "movement of irrigation water from a surface emitter " M.Sc. Thesis, Department of Water Resources College of Engineering University of Baghdad

6-Nimmo J. R., U.S. Geological Survey, Park M. (2004). Geological Survey, Menlo Park,(2004)" Porosity and Pore Size Distribution" CA 94025, USA Vol. 3, PP. 295-303.

7-Ministry of Water Resources, State Commission for Operation and Drainage Projects, Water Users Association Department, (9/11/2016).

8-Ministry of Agriculture, Directorate Agriculture of Karrbala (1/2/2017).

9-Ministry of Water Resources State Commission for Operation and Drainage Projects, Directorate of Water Resources Baghdad, (5/7/2017).

10-Neshat A. and Nasiri S. (2012) " Finding the Optimized Distance of Emitters in the Drip Irrigation in Loam-Sandy Soil in the Ghaeme Abad Plain of Kerman, Iran" Middle-East Journal of Scientific Research ISSN Vol. 11, No. 4,PP 426-434.
11-Gboekwe U. I. , Adindu R. U.(2014) "Use of Kostiakov's Infiltration Model on Michael Okpara University of Agriculture Umudike Soils, Southeastern, Nigeria" Journal of water resource and protection 2014, No.8, PP.888-894.

12-Schwartzman, M., and Zur, B. (1986). "Emitter spacing and geometry of wetted soil volume," J. Irrig. Drain. Eng., ASCE, Vol. 112, no. 3, pp. 242-253

13-Schaap, M. G., Leij, F. J., and Vangenuchten, M. Th. (2001). "ROSETTA: A computer program for estimating soil hydraulic properties with hierarchical pedotransfer functions," Journal of Hydrology, vol. 251, pp. 163-176.

14-Skaggs T. H.; Trout T. J.; imu ${ }^{\circ}$ nek J. S`; and Shouse P. J. (2004) "Comparison of HYDRUS-2D Simulations of Drip Irrigation with Experimental Observations" J. Irrig. Drain Eng.Vol.130, No.4, PP.304-310. 


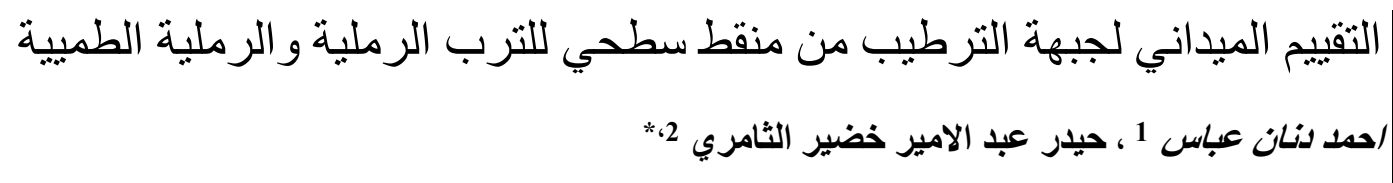

كلية الهندسة ، جامعة بغداد ،بغداد ، العراق، engnahmad_2014@yahoo.com hy_hyder@coeng.uobaghdad.edu.iq ، كلبة الهندسة ، جامعة بغداد ،بغداد ، العراق engnahmad_2014@yahoo.com : الباحث المثثل: احد دنان عباس البريب الاكترونسي " 2019 شر في: 28 حزيران

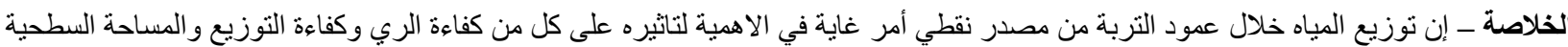

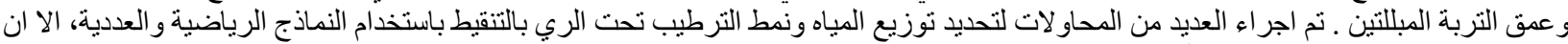

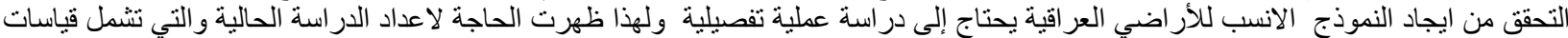

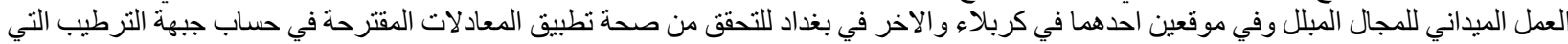

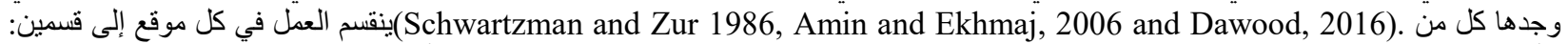

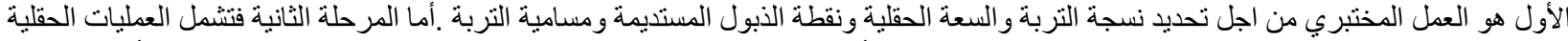

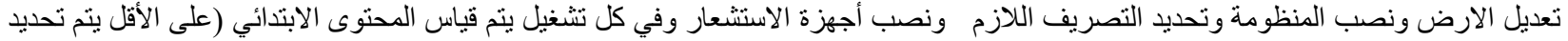

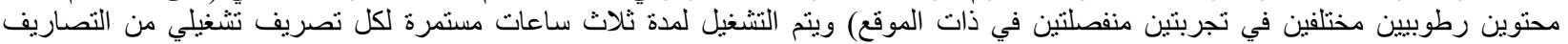

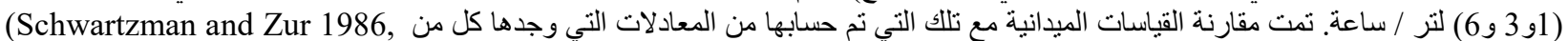
و Amin and Ekhmaj, 2006 and Dawood, 2016)

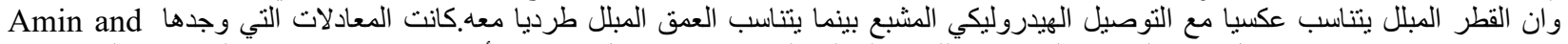

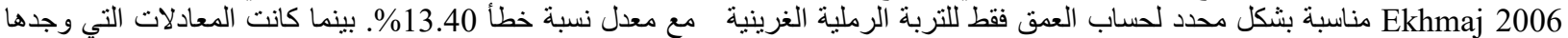
Schwartzman and Zur1986 هي الاقرب للنتائج الحقلية ولكن بشكل جزئي في حساب القطر المترطب فقط للتربة الرملية الغرينية مع معدل نسبة

خطأ 12.79\%

و اخير ا فان المعادلات التي وجدها Dawood, 2016 تعتبر الاكثر ملائمة من الاخرين و هي الانسب في التنبوء بمجال الترطيب للترب الرملية مع معدل

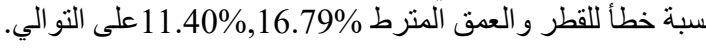

الكلمات الرئيسية ـ مجال الترطيب، الري بالتقفي، القطر الرطب، التقييم الحقلي. 